\title{
2. Funerary Treatment of Immature Deceased in Neolithic Collective Burial Sites in France. Were Children Buried with Adults?
}

\author{
MÉLIE LE ROY ${ }^{1}$, STÉPHANE ROTTIER², \\ FRÉDÉRIC SANTOS ${ }^{2}$, ANNE-MARIE TILLIER ${ }^{2}$
}

\begin{abstract}
Le Roy, M., Rottier, S. Santos, F. Tillier, A-m. 2018. Across the Generations: The Old and the Young in Past Societies. AmS-Skrifter 26, 21-33, Stavanger. ISSN 0800-0816, ISBN 978-82-7760-181-6.

In France, collective burial sites of the Late Neolithic period (3600-2100 BC) include a variety of structures ranging from simple pits and natural caves to hypogea and megalithic structures. The management of these graves raises questions about their representativeness and about burial practices involving non-adult individuals. This study of funerary selection based on age-at-death compares the results obtained for different sites and offers several potential interpretations concerning the integration of immature individuals in these collective tombs based on their age. The study highlights a particular selection observed in various funerary structures and a chronological difference between northern and southern France. These first results lead to a discussion of distinct cultural choices among different geographical areas.
\end{abstract}

Keywords: Neolithic; funerary selection; immature individuals; collective graves

Addresses: Archaeology and Palaeoecology, School of Natural and Built Environment, Queen's University Belfast, Belfast BT7 1NN, Northern Ireland ${ }^{1}$; UMR 5199, PACEA, University of Bordeaux, Bat. B8, Allée Geoffroy Saint Hilaire CS 50023, F - 33615 Pessac CEDEX ${ }^{2}$

Emails: melieleroy@hotmail.fr; stephane.rottier@u-bordeaux.fr; frederic.santos@u-bordeaux.fr; anne-marie.tillier@u-bordeaux.fr

\section{Introduction}

Neolithic sites (5700-2100 BC, according to Tarrête and Le Roux 2008) are plentiful in the French territory and a number have yielded human bones in various quantities. Osteological data allows us to understand the buried population from the perspective of funerary selection based on age (Masset 1987; 1990). This study focuses on a specific case namely the collective burial sites of the Late Neolithic in France (3600-2100 BC, according to Tarrête and Le Roux 2008); during this period this type of burial is particularly widespread (Soulier 1998; Chambon 2003). The collective aspect of the burials raises questions about the representativeness of the associated population and, more specifically, if children were buried in the same location as adults. As such, the aim of this study is to assess the proportion of immature deceased by assessing age-at-death, which is more accurate and reliable for immature individuals than for adults. The hypothesis that some juveniles were excluded from these sites because of their age, or as a consequence of the particular selection of certain age classes, will be tested.

\section{Material and Methods}

\section{Inventory}

To provide a reliable sample of archaeological sites for the analysis an inventory of collective burial sites dated to the Late Neolithic was compiled for France. This work was based on an exhaustive review of the archaeological literature regarding these funerary sites as well as on data derived from our own work (Bec Drelon et al. 2014; Le Roy et al. 2014; Le Roy 2015). A total of 333 collective burial sites, known to have produced human skeletal remains, were identified and classified by municipality, a sufficient scale given that the general objective of the inventory was to provide a sense of the distribution of available data (Fig. 1). The archaeological and anthropological data describing these graves were entered into a database. 
Table 1: Inventory of collective burial sites from Late Neolithic France with archaeological and biological data ("Dates presented by $B P ; * *$ Estimated age of immature individuals determined on the basis of the descriptions and illustrations contained in the associated publications) and allocation to each of the four funerary types (see Table 2).

\begin{tabular}{|c|c|c|c|c|c|c|c|}
\hline Site & Date (BC) & Structure & Location & MNI & $\begin{array}{c}\text { Immature } \\
\text { MNI }\end{array}$ & $\begin{array}{l}\text { Type of } \\
\text { funerary } \\
\text { selection }\end{array}$ & Sources \\
\hline Aillevans 2 & $2200-1900$ & Megalith & Open Area & 23 & 6 & 2 & $\begin{array}{l}\text { Chaix 1976; Pétrequin 1985; } \\
\text { Soulier } 1998\end{array}$ \\
\hline Aven de la Boucle & $4200+-100$ * & Surface & Cave & 75 & 10 & 2 & Duday 1999; Jallet et al. 2013 \\
\hline Aven Ka & & Surface & Cave & 5 & 2 & 1 & Le Roy 2015 \\
\hline Bas des Renardières & & Pit & Open Area & 15 & 7 & 1 & $\begin{array}{l}\text { Ledran 1994; Soulier 1998; } \\
\text { Chambon } 2003\end{array}$ \\
\hline Camp des Armes & & Chest & Cave & 9 & 4 & 1 & Pons et al. 1997 \\
\hline Can Pey & $4420+-120^{*}$ & Pit & Cave & 64 & 12 & 2 & $\begin{array}{l}\text { Chaddaoui 1994; Baills and } \\
\text { Chaddaoui } 1996\end{array}$ \\
\hline Champ Tortu & & Pit & Open Area & 8 & 1 & 1 & Bach 1995; Dubouloz et al. 2005 \\
\hline Clos d'Ayan & $2200-2000$ & Surface & Cave & 36 & 13 & 2 & Beeching et al. 1987 \\
\hline Dolmen 2 du Frau & & Megalith & Open Area & 64 & 33 & 3 & Pajot and Clottes 1975 \\
\hline Dolmen de Deveza & & Megalith & Open Area & 70 & 19 & 2 & Millau et al. 1958 \\
\hline Dolme de la Bouissière & $2565-2470$ & Megalith & Open Area & 15 & 4 & 1 & Roudil and Bérard 1981 \\
\hline Dolmen de la Caumette & & Megalith & Open Area & 26 & 7 & 2 & Bec Drelon et al. 2014 \\
\hline Dolmen de la Chatre & & Megalith & Open Area & 12 & 6 & 4 & Chaix 1976; Chambon 2000 \\
\hline Dolmen de la Haute Suane & & Megalith & Open Area & 43 & 8 & 2 & $\begin{array}{l}\text { Sauzade et al. 1988; Chambon } \\
\text { 2000; } 2003\end{array}$ \\
\hline Dolmen de la Pierre Folle & $2300-2400$ & Megalith & Open Area & 40 & 11 & 2 & $\begin{array}{l}\text { Brabant 1976; Joussaume 1976; } \\
1981\end{array}$ \\
\hline Dolmen de la Prunarède 1 & & Megalith & Open Area & 51 & 12 & 2 & Le Roy 2015 \\
\hline Dolmen de Piedcourt Nord & & Megalith & Open Area & 16 & 4 & 2 & Chateauneuf et al. 2010 \\
\hline Dolmen de San Sebastien 2 & & Megalith & Open Area & 78 & 5 & 2 & Sauzade 1988 \\
\hline Dolmen de Villaine & & Megalith & Open Area & 122 & 48 & 2 & Riquet 1972 \\
\hline Dolmen des Isserts & & Megalith & Open Area & 10 & 4 & 1 & Bec Drelon et al. 2014 \\
\hline Dolmen des Périères & & Megalith & Open Area & 87 & 46 & 3 & $\begin{array}{l}\text { Duday et al. 1985; Demangeot } \\
2008\end{array}$ \\
\hline Dolmen du Gloup de Goutz & & Megalith & Open Area & 19 & 8 & 1 & Pajot and Clottes 1975 \\
\hline Dolmen les Places & & Megalith & Open Area & 34 & 16 & 2 & Valentin 1997 \\
\hline Essômes sur Marne & $2308-1648$ & Hypogea & Buried & 40 & 11 & 3 & $\begin{array}{l}\text { Masset 1995; 1997; Chambon } \\
\text { and Salanova 1996; Le Mort } 1997\end{array}$ \\
\hline Eteauville & & Megalith & Open Area & 90 & 26 & 2 & Nouel et al. 1965 \\
\hline Foletière & & Megalith & Open Area & 42 & 26 & 3 & Patte 1966 \\
\hline Fosse Gosset & $3294-2499$ & Megalith & Buried & 66 & 11 & 2 & Kurzawski et al. 1982 \\
\hline Gours aux Lions 1 & & Pit & Open Area & 8 & 3 & 1 & Mordant and Mordant 1970 \\
\hline Gours aux Lions 2 & & Pit & Open Area & 53 & 23 & 1 & Mordant and Mordant 1970 \\
\hline Cave 2 de la Trache & & Surface & Cave & 7 & 2 & 1 & Riquet 1962 \\
\hline
\end{tabular}




\begin{tabular}{|c|c|c|c|c|c|c|c|}
\hline Site & Date $(B C)$ & Structure & Location & MNI & $\begin{array}{c}\text { Immature } \\
M N I\end{array}$ & $\begin{array}{l}\text { Type of } \\
\text { funerary } \\
\text { selection }\end{array}$ & Sources \\
\hline Cave d'Artigaou & $3720+-140$ * & Surface & Cave & 10 & 9 & 4 & Omnes 1980; 1987 \\
\hline Cave de Las Costos & & Surface & Cave & 27 & 2 & 2 & Jammes and Queyre 1981 \\
\hline Cave du Fournet & & Surface & Cave & 16 & 2 & 2 & Anthony $1912^{* *}$ \\
\hline Cave Laplace & $2864-2461$ & Surface & Cave & 5 & 2 & 1 & Blanc 1989; Marsan 1989 \\
\hline Hypogea de l'Homme Mort & $2902-1787$ & Hypogea & Buried & 20 & 12 & 3 & Jagu 1997 \\
\hline Hypogea des Crottes (C2) & $2940-2195$ & Hypogea & Buried & 130 & 58 & 3 & Courtin 1974; Chambon 2003 \\
\hline Justice & & Megalith & Open Area & 8 & 3 & 1 & Bailloud 1974 \\
\hline La Butte Saint-Cyr & & Megalith & Buried & 109 & 34 & 2 & Billard et al. 2010 \\
\hline La Ferme du Port & 3000 & Megalith & Buried & 65 & 21 & 2 & $\begin{array}{l}\text { Degros and Tarrête 1975; } \\
\text { Chambon and Salanova } 1996\end{array}$ \\
\hline La Gandille & & Megalith & Buried & 6 & 3 & 1 & Villes 1996 \\
\hline La Lécune & & Megalith & Open Area & 19 & 5 & 2 & $\begin{array}{l}\text { Plages 1973; Pajot and Clottes } \\
1975\end{array}$ \\
\hline La Madeleine & & Surface & Cave & 21 & 6 & 2 & Sauzade and Duday 1976 \\
\hline La Truie Pendue & $3360-3098$ & Pit & Open Area & 66 & 31 & 3 & Le Roy et al. 2014; Le Roy 2015 \\
\hline Laris-Goguet & & Chest & Cave & 110 & 40 & 2 & Bendezu-Sarmiento 1999 \\
\hline Le Blanc Val & & Megalith & Buried & 40 & 6 & 2 & Genet Varcin 1966 \\
\hline La Paradis 2 & $3510-2916$ & Pit & Open Area & 17 & 14 & 4 & Chambon 2003 \\
\hline La Vieux Tordoir & $3340-2936$ & Pit & Open Area & 32 & 13 & 2 & Dubuloz et al. 2005 \\
\hline Le Villard 2 & $2900-2100$ & Megalith & Open Area & 27 & 14 & 3 & Sauzade 2011 \\
\hline Les Maillets & $2872-2138$ & Pit & Open Area & 43 & 13 & 2 & Baumann and Tarrête 1979 \\
\hline Les Mournouards 2 & $2600-1700$ & Hypogea & Buried & 79 & 38 & 3 & $\begin{array}{l}\text { Leroi-Gourhan et al. 1962; Blin } \\
2012\end{array}$ \\
\hline Les Réaudins & & Pit & Open Area & 52 & 2 & 2 & Chambon and Mordant 1996 \\
\hline Montiou & $2515-1870$ & Megalith & Open Area & 18 & 9 & 1 & Chambon 2000; 2003 \\
\hline Moulin du Roc & 4390 * & Surface & Cave & 6 & 3 & 1 & Detrain et al. 1996 \\
\hline Pente de Courdelles & $4036-3641$ & Surface & Cave & 19 & 9 & 1 & $\begin{array}{l}\text { Chambon and Salanova 1996; } \\
\text { Chambon } 2003\end{array}$ \\
\hline Piedcourt 2 & & Megalith & Open Area & 9 & 3 & 1 & Chateauneuf et al. 2010 \\
\hline Piedcourt 4 & & Pit & Open Area & 10 & 4 & 1 & Chateauneuf et al. 2010 \\
\hline Piedcourt 5 & & Pit & Open Area & 12 & 2 & 1 & Chateauneuf et al. 2010 \\
\hline Porte Joie 1 & $3316-2926$ & Megalith & Open Area & 73 & 29 & 2 & Billard et al. 2010 \\
\hline Porte Joie XIV & $3090-2904$ & Megalith & Open Area & 27 & 10 & 1 & Billard et al. 2010 \\
\hline Rec d'Aigues Rouges & $2561-2213$ & Surface & Cave & 6 & 3 & 1 & Courtaud and Janin 1994 \\
\hline Reischttet 2 & $3637-3549$ & Pit & Open Area & 11 & 4 & 1 & Blaizot et al. 2001a \\
\hline Tumulus de Belleville & & Hypogea & Buried & 150 & 40 & 3 & Gatto 2007 \\
\hline Tute de l'Arrouza & & Surface & Cave & 6 & 1 & 1 & Omnes 1980; 1987 \\
\hline Varennes & $3509-2893$ & Megalith & Buried & 30 & 10 & 2 & Billard et al. 2010 \\
\hline
\end{tabular}




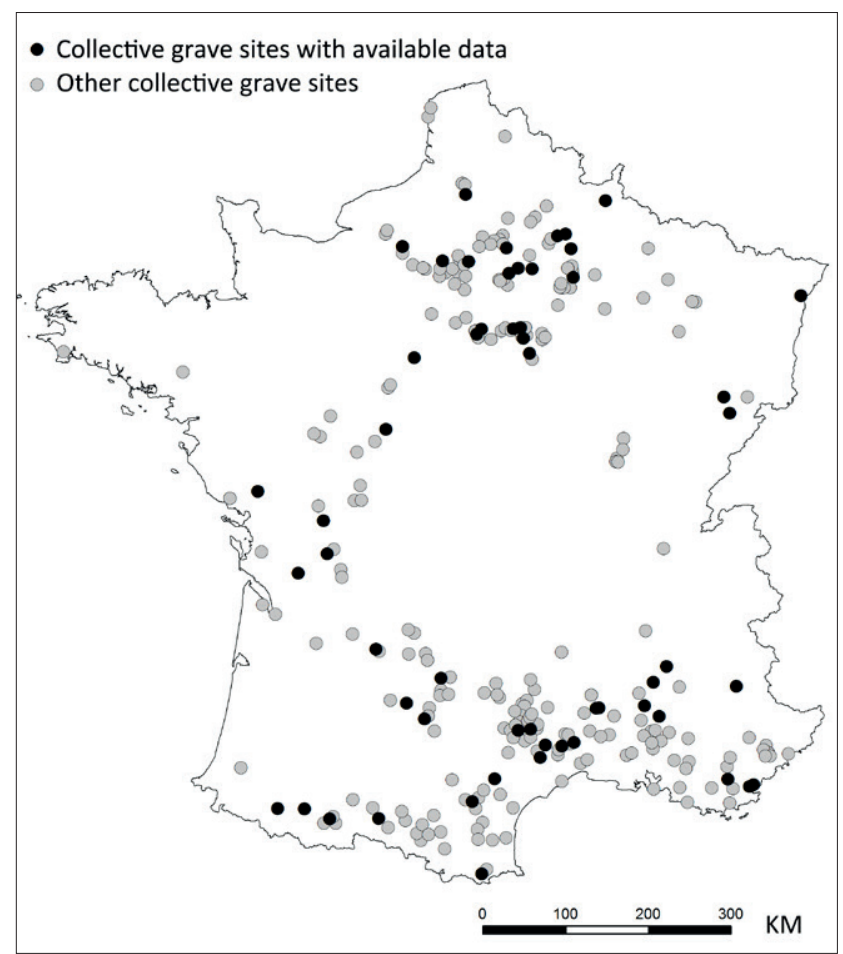

Figure 1: Distribution of collective graves with human bones from the Late Neolithic France based on the available data.

Archaeological information included details of the different types of structures uncovered (pits, megalithic tombs), site location (outdoor, cave, buried) and biological data relating to the skeletons unearthed (minimum number of individuals, number of immature individuals, ages attributed to the latter). To avoid significant methodological bias in the comparison of the archaeological sites only those that yielded bones, and for which the methods used to assess age-at-death were mentioned in publications and considered reliable (e.g. Moorrees et al. 1963a; 1963b; Fazekas and Kosa 1978; Ubelaker 1979; Scheuer and Black 2000), were included. The final analysis included a total of sixty-five collective graves distributed mainly between the Paris Basin in the north of France and the Mediterranean in the south (see Fig. 1; Table 1).

\section{Study of Funerary Selection Based on Age-at-death}

Immature individuals are normally sub-divided into age classes, which are generally used in demographic studies of archaeological population groups ([0], [1-4], [5-9], [10-14], [15-19]; e.g. Masset 1987; Sellier 1996; Séguy and Buchet 2011). Mortality quotients are used to establish a mortality profile for each grave when the premise of a stationary population is accepted for each site. This assumes a long period of occupation, consistent with the collective nature of the burial site, which potentially suggests a compensatory rate of birth and death (Halley hypothesis) (Sellier 1996).

Mortality profiles obtained for each burial site are then compared to a theoretical mortality model based on standard tables published by Ledermann (1969), corresponding to a so-called 'pre-Jennerian' population (i.e. before the industrial revolution and advances in healthcare such as the vaccination against smallpox). This implies that the same mortality pattern is true for each prehistoric population - a low life expectancy at birth (between 25 and 35 years), with a high mortality rate for younger children ( 0 to 4 years), and a low rate for older immature individuals (between 10 and 14 years, Ledermann 1969; Sellier 1996). Note that this method provides an 'average picture' of reality, smoothing potentially complex demographic events that may arise at specific times (Buchet and Séguy 2002). Although we do not know the exact mortality rate of ancient societies, observations on 'pre-Jennerian' populations are most likely to be comparable to the Neolithic populations and follow the same pattern of archaic mortality. Nevertheless, the purpose of this comparison is only to demonstrate any over- or under-representation of age classes in relation to a so-called 'natural' mortality rate and in no case to establish an accurate mortality profile for Neolithic populations.

Age-at-death assessments of immature individuals are not always consistent with the age classes conventionally used in demographic studies. As a consequence of difficulties, related to the state of conservation of the bones and the variable accuracy of the methods used, some individuals cannot be assigned with certainty to an age group. To overcome the methodological problems regarding the potential overlap of ages-at-death of immature individuals between two age groups we applied the principle of minimisation of anomalies (Sellier 1996), allowing us to redistribute all immature individuals among the age groups used in the preparation of mortality patterns. This redistribution of immature individuals is performed in a way that the distribution of age classes approaches the ratios expected for theoretical values of natural mortality - the ratio of [5-9 years] to [10-14 years] exceeds two, and the ratio of [5-14 years] to [> 20 years] lies between 0.1 and 0.3 (Bocquet and Masset 1977). Therefore, after this redistribution, any anomaly that still exhibits a departure from natural mortality rates is considered to be 'irreducible' (Sellier 1996).

To demonstrate the significance of the differences observed between the calculated mortality profile 
and the theoretical values the deviation between the observed mortality rate in a given age group and the theoretical probability of dying was calculated separately. ${ }^{1}$ The probabilities of death in each age group were then subjected to a standard test for comparison of proportion to a reference value using the binomial distribution. Statistical analyses were performed using R software 3.0.2 (Team 2013). ${ }^{2}$

\section{Spatial Analysis}

To discuss the spatial distribution of archaeological sites based on the results of the study of funerary selection based on age-at-death (see below the identification of funerary selection scenarios) and these sites' association with an identified type of structure, the average centre (or centroid) and the standard ellipse of the distribution of the collective burial sites were calculated.
The first is a representative indicator, namely the central point of the spatial distribution of sites. The second is a measure of dispersion of values around the centre of gravity at a standard distance. This standard ellipse encompasses $60 \%$ of the data points (provided that the spread follows a normal distribution) and is used to represent the intensity of the dispersion (or at least a characteristic distribution) of the sites. It may also characterise the dispersion according to the orientation of the ellipse's axes and their length, varying according to the deviations of the distance of the sites relative to the average centre. The nearest neighbour index was measured to identify the difference of the mean distance from the expected distance compared with the mean distance for a hypothetical random distribution; the index is calculated using the ratio between the two mean distances. Depending on the nature of the results, the distribution can be clustered,

\section{Shape of the mortality profile for each type of funerary selection}

Type 1

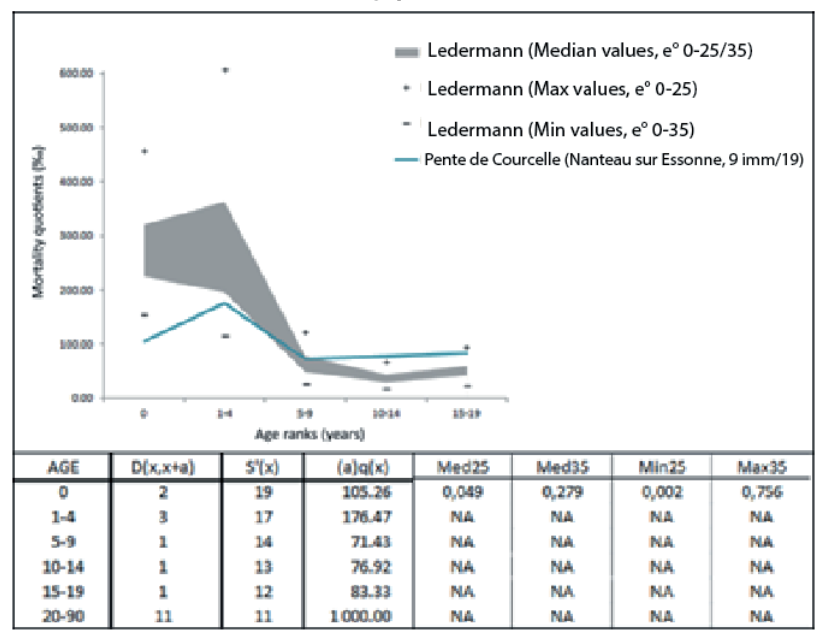

Type 3

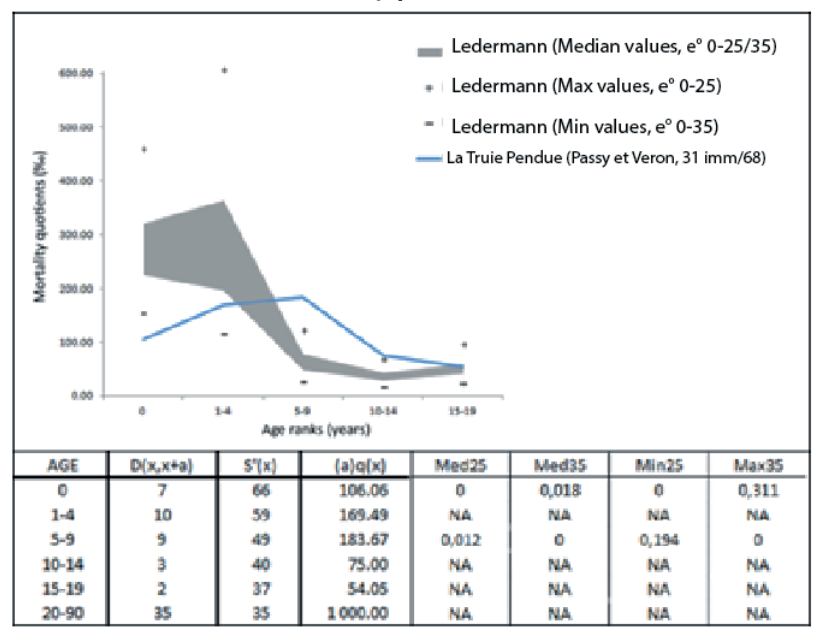

Type 2

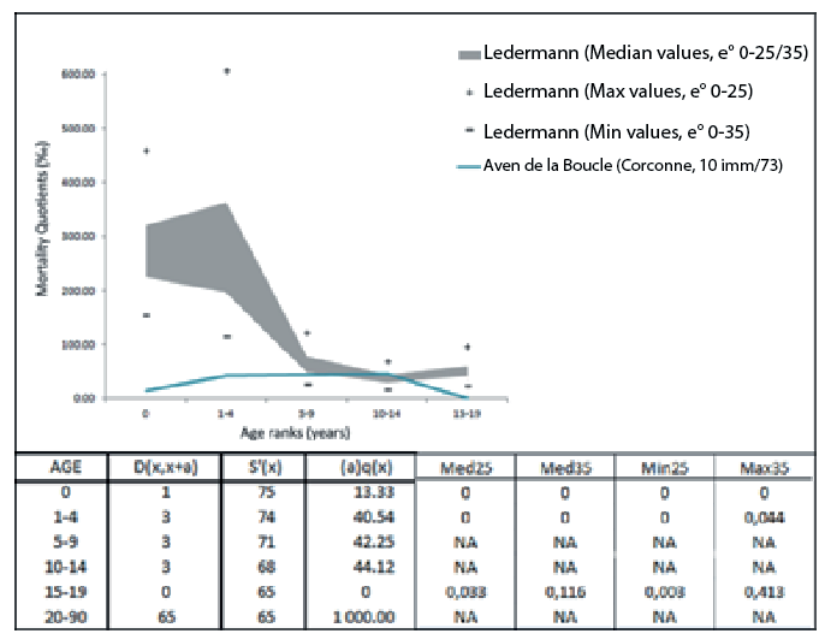

Type 4

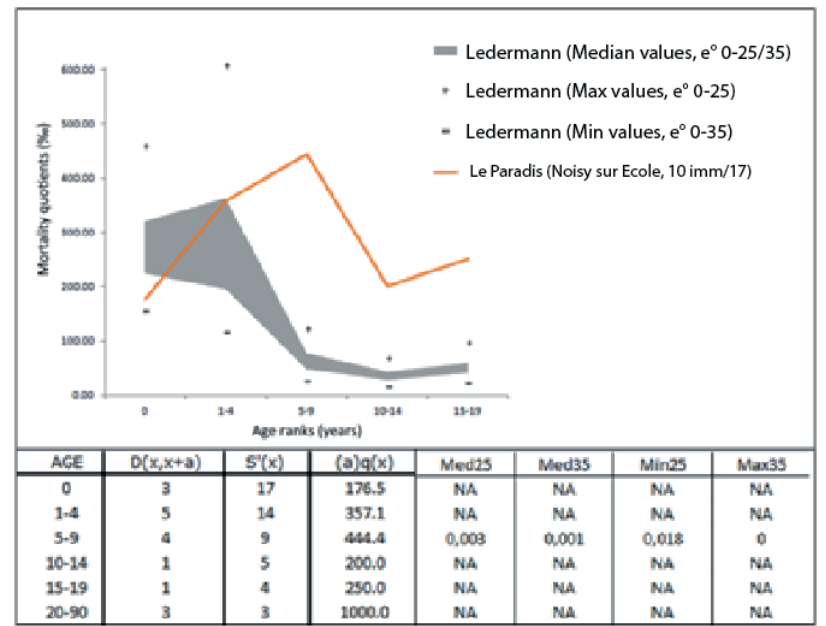

Figure 2: Mortality curves for the four major funerary types identified in the sample of collective burials from Late Neolithic France. 
Table 2: Description of the four major types of funerary selection identified in the sample of collective burials of Late Neolithic France, including the number of sites, the type of structures, the different types of identified anomalies, and the necessary conditions to make assumptions and interpretations when sources of bias could be eliminated.

\begin{tabular}{|c|c|l|l|l|l|l|}
\hline Type & $\begin{array}{c}\text { Number } \\
\text { of sites }\end{array}$ & $\begin{array}{l}\text { Type of } \\
\text { structures }\end{array}$ & Location & Identified anomaly & Conclusion & Possible interpretations \\
\hline 1 & 23 & $\begin{array}{l}\text { Chest-pit- } \\
\text { megalith }\end{array}$ & Cave-open area & None & $\begin{array}{l}\text { Perfect bone preservation; } \\
\text { exhaustive excavations }\end{array}$ & $\begin{array}{l}\text { Natural population at the start } \\
\text { of the bone assemblage }\end{array}$ \\
\hline 2 & 28 & $\begin{array}{l}\text { Chest-pit- } \\
\text { megalith }\end{array}$ & Cave-open area & $\begin{array}{l}\text { Under-representation } \\
\text { of the [0], or [1-4], or } \\
\text { [0-4] years }\end{array}$ & $\begin{array}{l}\text { Differential bone preservation } \\
\text { of the youngest indivdiuals, } \\
\text { non-exhaustive excavation, } \\
\text { error in the analysis } \\
\text { (identification, age-at-death } \\
\text { assessment) }\end{array}$ & Cultural choice \\
\hline 3 & 10 & $\begin{array}{l}\text { Megalith- } \\
\text { hypogea-pit }\end{array}$ & Open area & $\begin{array}{l}\text { Under-representation } \\
\text { of the [0-4] years and } \\
\text { over representation of } \\
\text { the [>5] years }\end{array}$ & $\begin{array}{l}\text { Error in the analysis } \\
\text { (identification, age-at-death } \\
\text { assessment) }\end{array}$ & $\begin{array}{l}\text { Cultural choice or catastrophic } \\
\text { mortality profile }\end{array}$ \\
\hline 4 & 3 & Megalith-pit & Cave-open area & $\begin{array}{l}\text { Over-representation } \\
\text { of the [>5] years }\end{array}$ & $\begin{array}{l}\text { Error in the analysis } \\
\text { (identification, age-at-death } \\
\text { assessment) }\end{array}$ & $\begin{array}{l}\text { Cultural choice or catastrophic } \\
\text { mortality profile or under- } \\
\text { representation of the adult } \\
\text { individuals }\end{array}$ \\
\hline
\end{tabular}

random or dispersed (Zaninetti 2005). Then, in order to identify these aggregates, we used the K Ripley's and Hotspot Analysis using Nearest Neighbour Hierarchical spatial clustering (Zaninetti 2005).

\section{Identification of Four Funerary Selection Scenarios}

For collective burials the total number of subjects is expressed by minimum number of individuals (MNI). This is an estimate, based on bone counts, that often underestimates the actual number of individuals buried within the structure and promotes the identification and enumeration of immature individuals (Chambon 2003). Four major types of funerary selection based on the age-at-death of immature individuals were observed within the sample of collective burials of the Late Neolithic period (Fig. 2 and Table 2).

The first type of funerary selection (Type 1) corresponds to a 'normal' mortality curve and no age class differs significantly from the expected theoretical values (see Fig. 2 and Table 2). The twenty-three sites attributed to this type were distributed uniformly over the entire study area (Fig. 3). No particular grave structure (megaliths, hypogea and caves) appears to have been favoured in the formation of these bone assemblages (see Table 2), which represent a natural selection. It is noteworthy, however, that some of the sites have an MNI of less than fifteen individuals. ${ }^{3}$ Such samples, due to their small size, do not facilitate the identification of significant differences in each of the age classes compared to the theoretical type of funerary selection. The observation of a significant number of sites belonging to funerary selection Type 1 must be qualified because of the preponderance of these small funerary assemblages (sixteen sites out of twentythree). A significant cluster of four sites appears in the Paris Basin (Fig. 4). These graves do not show any specific consistency in terms of their structure (three pits and a cave). Eight collective burial sites attributed to this type were subjected to radiocarbon dating - two in the Paris Basin were dated to between 4000 and 2800 BC (Chambon and Salanova 1996; Billard et al. 2010), that is, the first half of the Late Neolithic, while four southern sites and two on the Atlantic coast date to the second half of the Late Neolithic (2800-2200 BC, Roudil and Bérard 1981; Garcia and Duday 1983; Marsan 1989; Courtaud and Janin 1994).

Funerary selection Type 2 is characterised by a significant under-representation of one or two age groups below 5 years (see Fig. 2 and Table 2). The twenty-eight sites of this type are distributed evenly over the zones where collective burial sites are present (see Fig. 3). The majority are situated within megalithic structures (eighteen of the twenty-eight identified sites; see Table 2). All assemblages have an MNI higher than fifteen individuals (MNI ranging from sixteen to 122), thereby reducing any error in the identification of anomalies. Two clusters were identified, in the north and south of France (see Fig. 3). The southern group includes six sites and does not show any particular consistency in terms of structure (five megaliths and a cave), while 


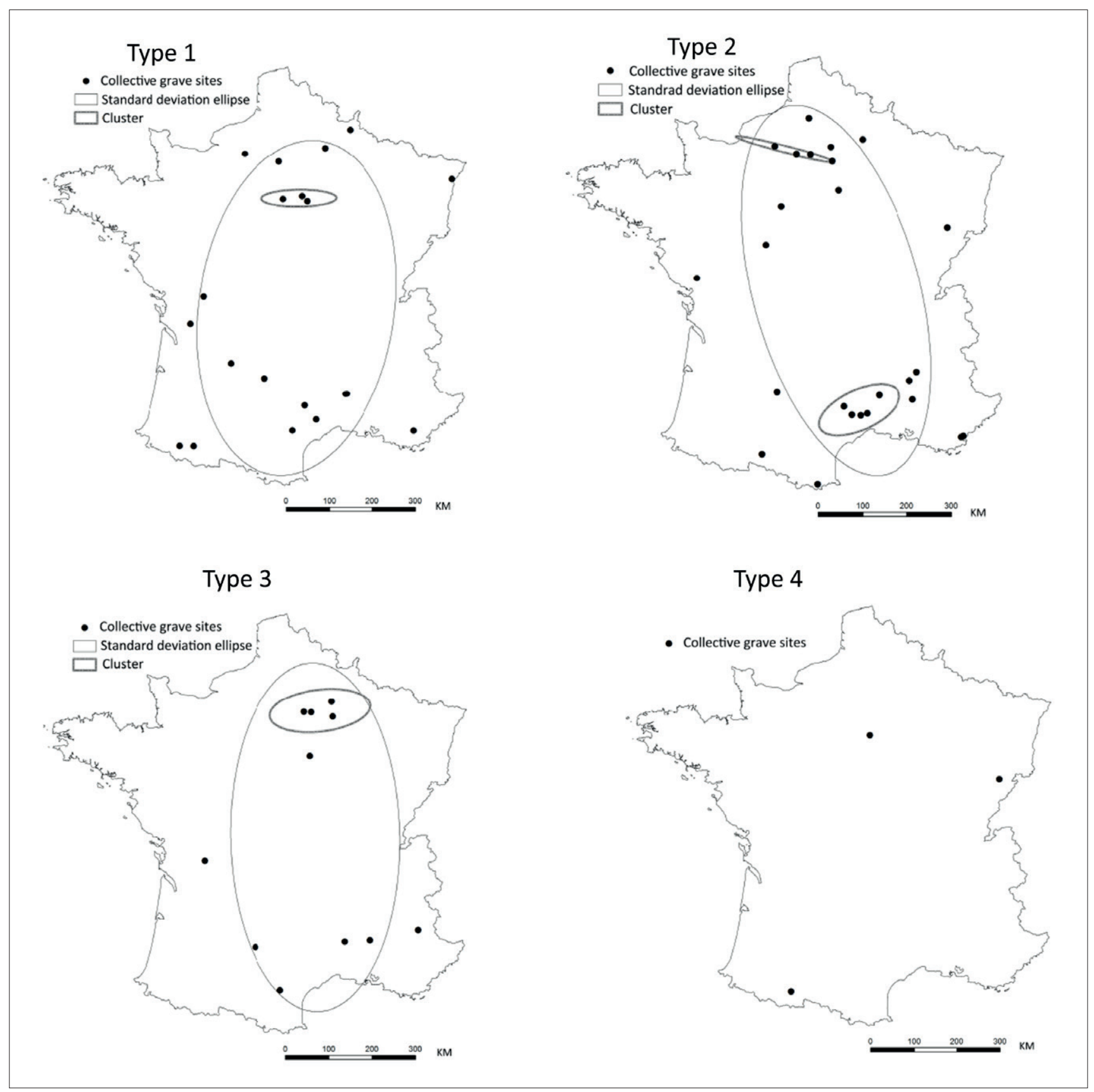

Figure 3: Distribution, deviational ellipse and concentration of sites representing funerary selection scenarios among the collective burial sites from Late Neolithic France.

the northern group includes five sites that all have the same type of structure, namely megaliths. As was the case for funerary selection Type 1 , the oldest dates were recorded in the north of France (3500-2800 BC, Chambon and Salanova 1996; Dubouloz et al. 2005; Billard et al. 2010), while more recent dates are recorded in both the north and south of France (2500-2000 BC, Joussaume 1981; Beeching et al. 1987; Baills and Chaddaoui 1996; Chambon and Mordant 1996).

Funerary selection Type 3 includes both an underrepresentation of younger children (less than 5 years) and an over-representation of older immature individuals (greater than 5 years) (see Fig. 2 and Table 2 ). This type includes ten sites and is observable again in both the north and south of France (see Fig. 3), but with a preponderance of examples in the north. Bone assemblages included in this type are generally substantial (MNI from twenty to 150) and the sites include all kind of structures, with the exception of caves (see Table 2). Similarly to Type 1, only one significant concentration was identified in the Paris Basin (see Fig. 3). There are four hypogea, representing consistency in terms of the structure type. On the basis of radiocarbon dating, prior to $3000 \mathrm{BC}$ this type of funerary 
Figure 4: Distribution of the sites and deviational ellipses showing underrepresentation and over-representation of immature individuals among the collective burial sites from Late Neolithic France.

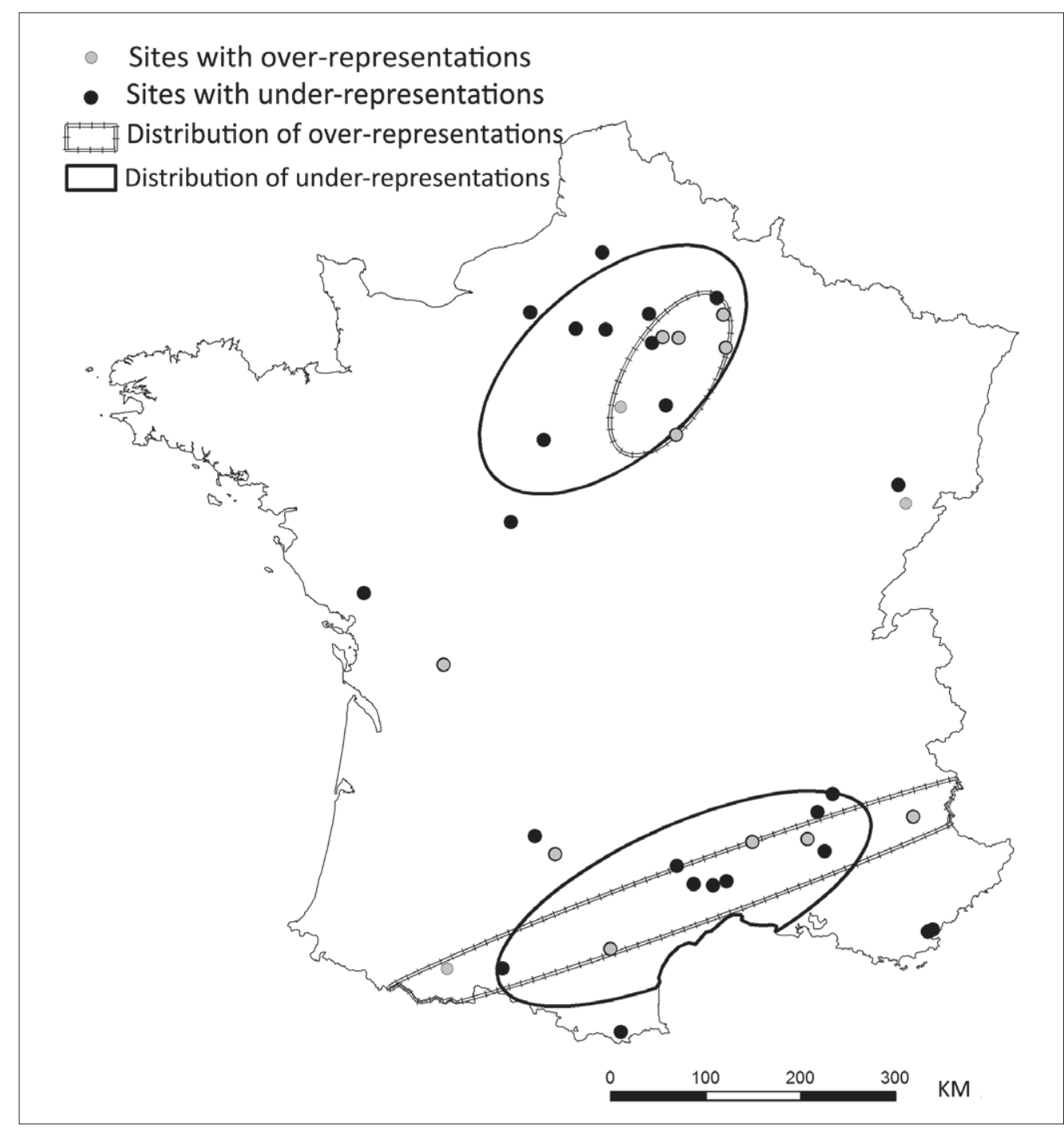

selection is observable in megalithic structures as well as in pits. From 2900 BC it is observed exclusively within hypogea, both in the north and south of France (Chambon and Salanova 1996; Salanova et al. 2011; Blin 2012).

Funerary selection Type 4 shows a significant overrepresentation of one or more age groups (see Fig. 2 and Table 2). In this type, only children aged greater than 5 years are over-represented. These age groups have the lowest expected mortality rates according to natural mortality models (e.g. Ledermann 1969). In addition, this type includes only three sites: two of which reveal an over-representation of the [5-9 years] age group, while the third shows an over-representation of the [15-19 years] age group (see Fig. 3). In this particular example of Neolithic collective graves, despite all of the precautions taken in the sampling (see above), the disparity of their geographical location, the very low number of sites involved, and in particular the time period of excavations and studies strongly suggest a methodological bias (e.g. non-exhaustive excavation) or preservative issues. The result is probably also influenced by the small sample size of each collective burial site and, indeed, the MNI does not exceed seventeen individuals at any of the sites (Brezillon et al. 1973; Chaix 1976; Omnès 1987). In fact, the collective burial sites of the Neolithic illustrating funerary selection Type 4 cannot be considered truly representative of any particular funerary choice.

\section{Discussion}

Comparing one site to another can be difficult because of the heterogeneity of collected data and the composition of bone samples. In the four types of funerary selection identified above, however, several sites can be compared from a spatial point of view, allowing us to speculate as to the nature of funerary selection and to identify some trends regarding the treatment of children by age in these different scenarios. 
The first type of funerary selection (Type 1), which demonstrates a 'natural' mortality most often involves both perfect bone preservation and an exhaustive excavation (see Table 2). This type of curve may indicate that the entire population was buried in the same place without any exclusion based on age. The inability to identify anomalies must also be taken into account, however, as it may result from the small population size observed in a majority of the sites included in the study.

The second type of funerary selection (Type 2) gives rise to several inferences (see Table 2). The first involves the hypothesis of a differential preservation of the bones of younger individuals, as discussed in the literature (Guy et al. 1997; Bello et al. 2002). In the type of collective burial, where fragmentation of the bones is generally intense, an error in the identification and estimation of the age-at-death of individuals, particularly for young people, is a strong possibility no matter how reliable the method applied. The nonexhaustive nature of excavations cannot be excluded. Indeed, older excavations such as those carried out on the dolmen 'La Caumette' (Arnal et al. 1979) had delivered an MNI of twenty-one according to reliable methods. The resumption of the excavation of this megalithic structure has demonstrated the incomplete nature of the initial excavation since an untouched part of the sepulchral layer has been unearthed during more recent investigations. Combining data previously published with the new data enabled a review of the MNI and identified five additional individuals $(\mathrm{MNI}=26$; Bec Drelon et al. 2014). Once all potential methodological biases are rejected, however, the hypothesis of cultural selection becomes possible. Such a deficit within the sample would lead to the conclusion that individuals in age class [0] years and/or [1-4] years received different funerary treatment and were not included in the collective burial site with the older members of the population.

The third type of funerary selection (Type 3) also suggests various possible implications (see Table 2). Firstly, an error in the identification and removal of bones during the excavation, non-exhaustive fieldwork, or even an error in estimating the age-at-death of immature individuals are possible, as mentioned above. Cultural selection can also be considered, however, and such funerary complexes appear to have been used for the burial of older immature subjects with the youngest having been excluded. The possibility that a life crisis, due to an epidemic or a violent episode, was responsible for such a curve is also possible, as has already been demonstrated for more recent periods
(Castex and Drancourt 2005). A comparison with the archaeological (presence or absence of artefacts associated with war, such as weapons) and biological data (presence or absence of lesions suggestive of violence or pathology) is essential to confirm or refute this hypothesis (Guilaine and Zammit 2001). To date, only the case of Layer C2 of 'l'hypogée des Crottes' (Roaix) is recognised in the literature as having resulted from a catastrophic mortality profile due to an episode of violence. This hypothesis was supported by the presence of bones with signs of blunt-force trauma (Bouville 1980). Other sites have presented cases of injuries by arrowheads or other weapons (e.g. Les Baumes Chaudes, André and Boutin 1995; Grotte Sainte-Enimie, Morel and Baudoin 1928), but these examples are isolated cases, and the funerary sites in this study have not yet been the subject of research as detailed as that made for the tomb of Roaix (Beyneix 2007). In addition to the opportunistic use of existing structures, as is the case for the tomb of Roaix, where only a layer (C2) is identified as revealing a mortality crisis, the occurrence of other levels with collective deposits make it difficult to identify such an event in an archaeological context. Additional studies on both previously excavated sites and newer ones could help to determine whether the case of 'l'hypogée des Crottes' (Roaix) is an exception.

The fourth type of funerary selection (Type 4) presents a strong methodological problem because a single age group is involved in each case. Indeed, the state of preservation of the bones renders it difficult to perform an anthropological study and an over- or under-estimation of age is possible. In addition, it is also conceivable that the excavation was not exhaustive, the studies being relatively old. The anomaly could also be due to the under-representation of adult individuals, however, particularly when several age groups are involved. This type of funerary selection is also discussed based on the number of individuals observed for each site. The study of funerary selection based on age-at-death compares the number of immature and adult individuals within a site. Indeed, if we artificially increase the numbers of adults observed over-representations tend to disappear (Sellier 1996).

Finally, within the full sample of collective burial sites of the Late Neolithic period, a deficit of children under five years is evident in the majority of sites (thirty-eight of sixty-five sites), as well as many sites with an over-representation of older children (thirteen of sixty-five sites). Note that in some types these anomalies are present simultaneously for the same site 
(funerary selection Type 3). The spatial distribution of these two demographic anomalies, unsurprisingly, covers both northern and southern France. However, the northern sites show a clear difference in their spatial distribution based on the detected anomalies: the under-representation of children under five years is mainly located in the western Paris Basin, while the over-representation of individuals over five years is concentrated in the eastern Paris Basin (Le Roy and Rottier in press). In the south, no spatial distinctions are observable between the different anomalies (see Fig. 4). The possibility of two distinct cultural influences in the Paris Basin is then possible, while in the south, funerary choices appear to be more homogeneous. However, this observation is due to the distribution of the available sample. Indeed, when looking for significant concentrations in the distribution of different funerary selections, significant clusters were identified in the north for the first three types (1,2 and 3 ), while in the south, only Type 2 showed significant clustering (see Fig. 3).

The homogeneity observed in the south of France does not necessarily imply an undifferentiated treatment of immature individuals, as it is not a representative sample of the identified sites. Significant concentrations of sites show a better representation of data in the north. The spatial distribution and the low number of southern sites can potentially hide a spatial distinction between the different compositions of funerary monuments. Thus, the northern sites show a clear difference in their spatial distribution based on the detected anomalies. This result allows us to contemplate a more detailed analysis. Indeed, if one considers the sites located in the Paris Basin and divides them according to their type of funerary selection (here Types 2, 3 and 4), a clear demarcation between the west and east of the geographical area is observed.

\section{Conclusions}

In conclusion, the identification of four types of distinct funerary selection in the sample of collective graves of the Late Neolithic period is accompanied by the realisation that, both in the north and south of France, children could be either excluded from or integrated into the burial community with older individuals. The current state of radiocarbon dating indicates a different chronology for some of these types: Types 1 and 2 seem to be present initially in the north, with the southern sites providing more recent dates. As such, the exclusion of the youngest individuals does not appear to reflect a chronological evolution. Moreover, certain types of structures among those observed seem to specialise in a particular funerary selection: in the hypogea, only the type combining the under-representation of individuals under five years and over-representation of older immature individuals (Type 3 ) is observable. ${ }^{4}$ The data strongly suggests that in such funerary structures the very youngest individuals were completely absent, while the older children were integrated within the adult corpus. Funerary selection Type 1 is relatively well distributed, however, thereby suggesting that children and adults were still quite often buried together. Nevertheless, the low number of individuals identified in the relevant collective graves probably accounts for this relative abundance. The bias identified in the fourth type of funerary selection, which contains only children aged greater than five years, may seem suggestive that these sites were deliberately dedicated to children. This interpretation is problematic, however, due to the small number of sites and low MNI values. As such, it seems probable at this juncture that no collective burial sites were dedicated solely to children.

Finally, although every type of funerary selection is observable throughout the French territory, it seems that differences between north and south are due firstly to the types of structure and, secondly, to different spatial distribution management of collective graves. Indeed, a cluster of sites exhibiting over-representation of immature individuals is observed in the eastern Paris Basin, while the western sites seem to exclude the youngest from the resting places used for the remainder of the population. This clear difference seems to echo the redefinition of the cultures in the Paris Basin, based on Late Neolithic artefacts (Salanova et al. 2011), but this time stressing differences in the child-adult relationship in death.

\section{Acknowledgements}

We especially want to thank Dominique Castex (UMR 5199 - PACEA) for constructive discussions to the realisation of this work (setting up models and significance tests between mortality patterns). We also thank Sacha Kacki (UMR5199 - PACEA) for his advice. This research received a Ministerial Fellowship, awarded to M. Le Roy by the School of Science and Environment of Bordeaux University. The work was also supported by assistance from the National Research Agency under the programme 'Future Investments', bearing the reference ANR-10-LabX-52 (LaScArBx, DHP project). 


\begin{abstract}
Notes
1. Approach initiated in the laboratory PACEA (UMR 5199) by P. Sellier and D. Castex, but which is not yet published.

2. The results and mortality curves for each site are available in Le Roy $(2015)<$ https://tel.archives-ouvertes.fr/tel-01229878 >.

3. Under this number of individuals the ratio immature individuals/whole population falls out of the range $36-74 \%$. This range, based on the mortality tables of Ledermann (1969), reflects the minimum and maximum proportions of a natural funerary selection in a case of an archaical mortality (Blaizot et al. 2001b).

4. This result should be considered to be preliminary since only a small number of hypogea have been studied sufficiently well to be included in the analysis.
\end{abstract}

\section{References}

André, J. and Boutin, J. Y. 1995. Les Baumes-Chaudes et les Trépanations Crâniennes dans les Grands-Causses. Mende: Association du Docteur Prunières.

Anthony, R. 1912. Note sur les ossements recueillis par M. le Dr Laval dans la grotte du Fournet. Bulletins et Mémoires de la Société d'Anthropologie de Paris 3, 65-70.

Arnal, J., Duday, H., Coularou, J. and Poulain, T. 1979. Le dolmen de la Caumette Notre-Dame de Londres (Hérault). Bulletin d'Etudes Préhistoriques Alpines Aosta 11, 23-60.

Bach, S. 1995. La sépulture collective de Cuiry-les-Chaudardes 'le Champ Tortu'. Revue Archéologique de Picardie 9, 155-64.

Bailloud, G. 1974. Le Néolithique dans le Bassin Parisien. Paris: CNRS.

Baills, H. and Chaddaoui, L. 1996. La sépulture collective de Can-Pey (Pyrénées-Orientales): étude des pratiques funéraires. Bulletins et Mémoires de la Société d'Anthropologie de Paris 8, 365-71.

Baumann, F. and Tarrête, J. 1979. Les fouilles et la structure. Interprétation. Gallia Préhistoire 22, 143-53.

Bec Drelon, N., Le Roy, M. and Recchia Quiniou, J. 2014. Autour de la chambre: nouveaux éléments de réflexion sur les structures tumulaires. Apport des fouilles récentes de cinq dolmens de l'Hérault, pp. 569-82 in Sénépart, I., Léandri, F., Cauliez, J., Perrin, T. and Thirault, E. (eds.), Chronologie de la Préhistoire Récente dans le Sud de la France: Acquis 1992-2012/Actualité de la Recherche. Toulouse: Archives d'Ecologie Préhistorique.

Beeching, A., Cordier, F., Crubezy, E. and Zammit, J. 1987. La grotte sépulcrale chalcolithique du Clos d'Ayan à Vesc (Drome), pp. 21-30 in Beeching, A. (ed.), Actes des Rencontres Néolithiques de Rhône-Alpes 3. Lyon: Université Lumière Lyon 1.

Bello, S., Signoli, M., Rabino Massa, E. and Dutour, O. 2002. Les processus de conservation différentielle du squelette des individus immatures. Implications sur les reconstitutions paléodémographiques. Bulletins et Mémoires de la Société d'Anthropologie de Paris 14, 245-62.

Bendezu-Sarmiento, J. 1999. Le 'Laris-Goguet' à Feigneux (Oise), une grotte sépulcrale de la fin du Néolithique. De nouvelles données à partir d'une étude, archéologique et anthropologique, effectuée sur les sujets immatures. Revue Archéologique de Picardie 1-2, 63-82.

Beyneix, A. 2007. Les comportements funéraires au Néolithique en France méridionale: une vue d'ensemble. L'Anthropologie 111, 68-78.
Billard, C., Guillon, M., Piera, S. and Tirran, C. 2010. La sépulture collective de Val-de-Reuil 'la Butte Saint-Cyr', pp. 125-204 in Billard, C., Guillon, M. and Verron, G., (eds.), Les Sépultures Collectives du Néolithique Récent-Final de Val-deReuil et Porte-Joie (Eure - France). Liège: ERAUL.

Blaizot, F., Boës, X., Lalaï, D., Le Meur, N. and Maigrot, Y. 2001a. Premières données sur le traitement des corps humains à la transition du Néolithique récent et du Néolithique final dans le Bas-Rhin: dimensions culturelles. Gallia Préhistoire 43, 175-235.

Blaizot, F., Bonnet, C., Castex, D. and Duday, H. 2001b. Trois cimetières ruraux de l'Antiquité tardive dans la moyenne vallée du Rhône. Les sites du Pillon à Marennes (Rhône), du Trillet à Meyzieu (Rhône) et des Girardes à Lapalud (Vaucluse). Gallia 58, 271-361

Blanc, C. 1989. Grotte 'Laplace' (Arudy, P.A.) premiers résultats de sondage. Archéologie des Pyrénées-Occidentales 9 , 103-6.

Blin, A. 2012. Une nouvelle analyse de l'hypogée néolithique des Mournouards II au Mesnil-sur-Oger (Marne). Revue Archéologique de l'Est 61, 35-54.

Bocquet, J. P. and Masset, C. 1977. Estimateurs en paléodémographie. L'Homme, 65-90.

Bouville, C. 1980. L'hypogée chalcolithique de Roaix. Apport de l'étude de la démographie en Provence. Bulletins et Mémoires de la Société d'Anthropologie de Paris 7, 85-9.

Brabant, H. 1976. Etude odontologique. Gallia Préhistoire 19, 51-60.

Brezillon, M., Girard, C., Degros, J., Tarrête, J., Poulain, T. and Girard, M. 1973. La sépulture collective du Paradis à Noisy-sur-École (Seine-et-Marne). Cahiers du Centre de Recherches Protohistoriques 1, 4-75.

Buchet, L. and Séguy, I. 2002. La paléodémographie: bilan et perspectives. Annales de Démographie Historique 1, 161-212.

Castex, D. and Drancourt, M. 2005. D'un site funéraire à la détection d'une crise épidémique. Identités biologiques et patrimoine génétique, pp. 190-209 in Gualde, N., Goubert, J. P. and Barry, S. (eds.), D'un Site Funéraire à la Détection d'une Crise Épidémique. Identités Biologiques et Patrimoine Génétique (Revue Sociologie Santé 22). Marseille: Les Études Hospitalières.

Chaddaoui, L. 1994. Etude Anthropologique d'une Sépulture Collective Néolithique: la Grotte de Can-Pey (Montferrer, Pyrénées-Orientales). Unpublished PhD thesis, University of Bordeaux 1.

Chaix, L. 1976. Etude des restes humains et animaux. Gallia Préhistoire 19, 383-94.

Chambon, P. 2000. Les pratiques funéraires dans les tombes collectives de la France Néolithique. Bulletin de la Société Préhistorique Française 97, 265-74.

Chambon, P. 2003. Les Morts dans les Sépultures Collectives Néolithiques en France: du Cadavre aux Restes Ultimes. Paris: CNRS.

Chambon, P. and Mordant, D. 1996. Monumentalisme et sépultures collectives à Balloy (Seine-et-Marne). Bulletin de la Société Préhistorique Française 93, 396-402.

Chambon, P. and Salanova, L. 1996. Chronologie des sépultures du IIIe millénaire dans le bassin de la Seine. Bulletin de la Société Préhistorique Française 93, 103-18.

Châteauneuf, F., Croizier, G., Scimia, R. and Venobre, J. P. 2010. La Nécropole de Rochegude: un Ensemble Funéraire du Néolithique Final à l'Age du Bronze en Languedoc Oriental. 
Anduze: Studio Passé Composé.

Courtaud, P. and Janin, T. 1994. La grotte sépulcrale chalcolithique du Rec d'Aigues Rouges à Saint-Pons-deThomières (Hérault). Gallia Préhistoire 36, 329-56.

Courtin, J. 1974. Le Néolithique de la Provence. Klincksieck: CNRS.

Demangeot, C. 2008. Le Dénombrement des Défunts dans les Ensembles Funéraires: Probèmes Théoriques, Paramètres Quantitatifs: Application à la Sépulture Collective du Dolmen des Peirières à Villedubert (Aude, France). Unpublished PhD thesis, University of Bordeaux 1.

Degros, J. and Tarrête, J. 1975. Etude archéologique. Gallia Préhistoire 18, 423-32.

Detrain, L., Guillon, M., Kervazo, B., Madeleine, S., Morala, A. and, Turq, A. 1996. Le Moulin du Roc à Saint-Chamassy (Dordogne). Résultats préliminaires. Bulletin de la Société Préhistorique Française 93, 43-8.

Dubouloz, J., Bostyn, F., Chartier, M., Cottiaux, R. and Le Bolloch, M. 2005. La recherche archéologique sur le Néolithique en Picardie. Revue Archéologique de Picardie 3-4, 63-98.

Duday, H. 1999. Corconne: Aven de la Boucle. Gallia 2000, 67.

Duday, H., Crubezy, E., Guillet, J., Henaff, S. and Lambach, F. 1985. Archéologie funéraire et anthropologie de terrain: le dolmen des Peirières à Villedubert (Aude). Lettre d'Information du Centre de Recherches Archéologiques 11, 43-7.

Fazekas, I. and Kosa, F. 1978. Forensic Foetal Osteology. Budapest: Akademiai Kiado.

Garcia, A. M. and Duday, H. 1983. Grotte de Foissac (Aveyron). A propos d'une découverte récente ou de l'ichnologie comme mode d'approche des structures préhistoriques en grotte. Bulletin de la Société Préhistorique Française 80, 184-7.

Gatto, E. 2007. La gestion de l'espace sépulcral dans les coffres de Genevray (Thonon-les-Bains, Haute-Savoie, France), pp. 177-94 in Moinat, P. and Chambon, P. (eds.), Les Cistes de Chamblandes et la Place des Coffres dans les Pratiques Funéraires du Néolithique Moyen Occidental. Lausanne: Cahiers d'Archéologie Romande.

Genet-Varcin, E. 1966. Les restes osseux des Presles. BMSAP 9, 255-67.

Guilaine, J. and Zammit, J. 2001. Le Sentier de la Guerre: Visages de la Violence Préhistorique. Paris: Edition Seuil.

Guy, H., Masset, C. and Baud, C. A. 1997. Infant taphonomy. International Journal of Osteoarchaeology 7, 221-9.

Jagu, D. 1997. La sépulture d'Essômes-sur-Marne (Aisne). Etude odontologique. Revue Archéologique de Picardie 1-2, 41-8.

Jallet, F., Duday, H. and Cours, S. 2013. Néolithique récent et Néolithique final de l'aven de la Boucle (Corconne, Gard), regards d'archéologues, pp. 243-56 in Jaubert, J., Fourment, N., Depape, P. (eds.), Transitions, Ruptures et Continuité en Préhistoire. Paris: Société Préhistorique Française.

Jammes, M. and Querre, J. 1981. La grotte sépulcrale de Las Costos, commune de Prat-Bonrepaux (Ariège). Bulletin de la Société Préhistorique Française 78, 274-9.

Joussaume, R. 1976. Dolmen de Pierre-Levée à Nieul-surl'Autize (Vendée). Bulletin de la Société Préhistorique Française 73, 398-421.

Joussaume, R. 1981. Les longs tumulus du Centre-Ouest de la France. Bulletin de la Société Préhistorique Française 78, 1-102.

Kurzawski, V., Blondiaux, J. and Marquet, N. 1982. Etudes en cours sur les populations anciennes du Nord de la France, du Néolithique à l'époque médiévale. Bulletins et Mémoires de la Société d'Anthropologie de Paris 9, 51-5.

Ledermann, S. 1969. Nouvelles Tables-Type de Mortalité. Paris: Presses Universitaires de France.

Ledran, J. Y. 1994. Pont-sur-Yonne, le Bas des Renardières: sépulture collective Néolithique. Bulletin des Anthropologistes de Basse-Normandie 10, 2-30.

Leroi-Gourhan, A., Bailloud, G., Brezillon, M. and Monmignaut, C. 1962. L'hypogée II des Mournouards (Mesnil-sur-Oger, Marne). Gallia Préhistoire 5, 23-133.

Le Mort, F. 1997. Les restes humains de la sépulture collective néolithique d'Essômes-sur-Marne (Aisne). Revue Archéologique de Picardie 1-2, 19-30.

Le Roy, M. 2015. Les Enfants au Néolithique: Du Contexte Funéraire à l'Interprétation Socioculturelle en France de 5700 à 2100 ans av. J.-C. Unpublished PhD thesis, University of Bordeaux.

Le Roy, M. and Rottier, S., in press. Traitement funéraire des enfants et groupes culturels : L'exemple du Bassin parisien à la fin du Néolithique, In Fromont, N. et Marchand, G. (Eds) Statut des objets, des lieux et des Hommes au Néolithique, Actes du 32ème colloque InterNéo.

Le Roy, M., Rottier, S., De Becdelièvre, C., Thiol, S., Coutelier, C. and Tillier, A-m. 2014. Funerary behaviour of Neolithic necropolises and collective graves in France. Evidence from Gurgy 'Les Noisats' (middle Neolithic) and Passy/ Véron 'La Truie Pendue' (Late Neolithic). Archäologisches Korrespondenzblatt 3, 337-51.

Marsan, G. 1989. La néolithisation dans le bassin d'Arudy, données actuelles, pp. 8-10 in Hubschman, J. and Jalut, G. (eds.), Glacier Pyrénéen, Versant nord/Versant sud. Paléoenvironnements du Pléistocène Supérieur et de l'Holocène. Toulouse: AFEQ.

Masset, C. 1987. Le 'recrutement' d'un ensemble funéraire, pp. 111-34 in Duday, H. and Masset, C. (eds.), Anthropologie Physique et Archéologie: Méthodes d'Etude des Sépultures. Toulouse: CNRS.

Masset, C. 1990. Où en est la paléodémographie? Bulletins et Mémoires de la Société d'Anthropologie de Paris 2, 109-21.

Masset, C. 1995. Une demeure d'éternité construite dans du sable: la sépulture collective d'Essômes-sur-Marne (Aisne). Revue Archéologique de Picardie 9, 131-3.

Masset, C. 1997. La sépulture collective d'Essômes-sur-Marne (Aisne). Revue Archéologique de Picardie 1-2, 5-17.

Millau, G., Poulain, T. and Marechal, J. 1958. Le dolmen à couloir du Devezas (Saint-Maurice-de-Navacelle, Hérault). Bulletin de la Société Préhistorique Française 55, 412-21.

Moorrees, C., Fanning, E. and Hunt, E. 1963a. Age variation of formation stages for ten permanent teeth. Journal of Dental Research 42, 1490-502.

Moorrees, C., Fanning, E. and Hunt, E. 1963b. Formation and resorption of three deciduous teeth in children. American Journal of Physical Anthropology 21, 205-13.

Mordant, C. and Mordant, D. 1970. Le site Néolithique des Gours-aux-Lions à Marolles-sur-Seine (Seine-et-Marne). Bulletin de la Société Préhistorique Française 67, 345-70.

Morel, C. and Baudoin, M. 1928. Un cas intéressant de pathologie préhistorique. Une pointe de silex dans une vertèbre Néolithique. Le Progrès Médical 25, 1042-52.

Nouel, A., Dauvois, M., Bailloud, G., Riquet, R. and PoulainJosien, T. 1965. L'ossuaire Néolithique d'Éteauville commune de Lutz-en-Dunois (Eure-et-Loir). Bulletin de la Société Préhistorique Française 62, 576-648. 
Omnès, J. 1980. L'ossuaire de la grotte d'Artigaou à Esparros (H.-P.) suivi d'un inventaire des grottes sépulcrales des Hautes-Pyrénées. Revue de Comminges Saint-Gaudens 93, $161-74$.

Omnès, J. 1987. Les hommes, les grottes et la mort dans les Hautes-Pyrénées in Les hommes et leurs sépultures dans les Pyrénées Occidentales, depuis la préhistoire. Catalogue de l'exposition. Archéologie des Pyrénées Occidentales et des Landes 7, 117-20.

Pajot, B. and Clottes, J. 1975. Le dolmen 2 du Frau, à Cazals (Tarn et Garonne). Bulletin de la Société Préhistorique Française 72, 382-401.

Patte, E. 1966. Le dolmen de la Foletière à Luxé (Charente). Gallia Préhistoire 9, 419-35.

Petrequin, P. 1985. Les sépultures collectives de la fin du Néolithique en Haute-Saône. Une révision des données. Revue Archéologique de l'Est et du Centre-Est 36, 13-82.

Plages, P. 1973. Etude odontologique du dolmen de la Lecune. Bulletin de la Société Préhistorique Française 70, 154-6.

Pons, F., Bruxelles, L. and Staniasek, L. 1997. L'Abri Sépulcral du Camp des Armes (Lapanouse-de-Cernon, Aveyron). Toulouse: SRA Midi-Pyrénées.

Roudil, O. and Bérard, G. 1981. Les Sépultures Mégalithiques du Var. Paris: CNRS.

Riquet, R. 1962. Les ossements humains de la grotte 2 de la Trache à Chateaubernard (Charente). Bulletin de la Société Préhistorique Française 59, 456-63.

Riquet, R. 1972. Etude anthropologique. Gallia Préhistoire 15, 93-110.

Salanova, L., Brunet, P., Cottiaux, R., Hamon, T., Langry, F., Martineau, R., Polloni, A., Renard, C. and Sohn, M. 2011. Du Néolithique récent à l'Age du bronze dans le centre de la France: les étapes de l'évolution chrono-culturelle. Revue Archéologique de Picardie 28, 77-101.

Sauzade, G. 1988. Le dolmen II de San Seabastien, communes de Plan-de-la-Tour et Sainte-Maxime (Var). Gallia Préhistoire 30, 119-43.

Sauzade, G. 2011. Caractérisation chronoculturelle du mobilier funéraire en Provence au Néolithique final et au Bronze ancien. Préhistoires Méditerranéennes 2, 1-33.

Sauzade, G. and Duday, H. 1976. L'abri de la Madeleine (Bédoin, Vaucluse). Bulletin du Musée d'Anthropologie Préhistorique de Monaco 20, 97-123.

Sauzade, G., Courtin, J. and Chabaud, G. 1988. Le dolmen de la Haute-Suane (Grimaud-Sainte-Maxime, Var) et la tombe circulaire en blocs de l'Amourié (Grimaud). Bulletin de la Société Préhistorique Française 85, 148-59.

Scheuer, L. and Black, S. 2000. Developmental Juvenile Osteology. London: Academic Press.

Séguy, I. and Buchet, L. 2011. Manuel de Paléodémographie. Paris: Ined.

Sellier, P. 1996. La mise en évidence d'anomalies démographiques et leur interprétation: population, recrutement et pratiques funéraires du tumulus de Courtesoult, pp. 118-202 in Piningre J. F. (ed.), Nécropoles et Société au Premier Age du Fer. Le Tumulus de Courtesoult (Haute-Saône). Paris: Editions de le Maison des Sciences de l'Homme.

Soulier, P. 1998. La France des Dolmens et des Sépultures Collectives (4500-2000 avant J.-C.). Paris: Editions Errance.

Tarrête, J. and Le Roux C. T. 2008. Le Néolithique. Paris: Editions Picard.

Team R.D.C. 2013. R: A Language and Environment for Statistical Computing. R Foundation for Statistical Computing < http://www.R-project.org >.

Ubelaker, D. H. 1979. Human Skeletal Remains. Excavations, Analysis and Interpretation. Washington: Smithsonian Institute Press.

Valentin, F. 1997. Variabilité humaine au Néolithique récent final dans le Bassin Parisien. Gallia Préhistoire 39, 239-54.

Villes, A. 1996. Sépultures collectives du Néolithique en Champagne: recherche d'une identité régionale. Bulletin de la Société Préhistorique Française 93, 312-7.

Zaninetti, J. M. 2005. Statistique Spatiale. Méthodes et Applications Géomatiques. Paris: Lavoisier. 